\title{
APLIKASI TEPUNG DAUN KAYU MANIS SEBAGAI SUPLEMEN PAKAN TERHADAP KUALITAS DAGING UDANG VANAME (Litopenaeus vannamei)
}

\author{
(Application of Cinnamon Leaf Flour as Feed Supplement to Meat Quality of \\ Vannamei Shrimp (Litopenaeus vannamei)) \\ Neny Mariyani ${ }^{1)}$, Andri Hendriana ${ }^{1)}$ \\ ${ }^{1)}$ Sekolah Vokasi, Institut Pertanian Bogor, Jl. Kumbang no 14, Bogor, Jawa Barat \\ E-mail : neny.mariyani@apps.ipb.ac.id
}

\begin{abstract}
This study aims to apply the application of cinnamon leaf flour as feed supplement to meat quality of vannamei shrimp (Litopenaeus vannamei). The concentrations of cinnamon leaf flour given were $0 \%, 0,5 \%, 1,0 \%$ and $1,5 \%$. The vannamei shrimp used had an average weight of 10,06 $\pm 0,15 \mathrm{~g} /$ tail which was kept in an aquarium for 60 days. The result of proximate analysis showed no difference in water content, ash, protein, fat, and crude fiber of shrimp meat $(p>0,05)$ and glucose content showed significant difference $(p<0,05)$. The result of organoleptic test on quality of shrimp meat showed no difference in aroma, color, taste and texture that could be detected by the panelists ( $p>0,05)$. The average response were: aroma 4,43, 4,31, 4,45; color 4,67, 4,67, 4,60; texture 4,52, 4,67, 4,52 and taste 4,48, 4,38, 4,52. From the result of the organoleptic test, all parameters showed a number above 4 , where the value of 4 indicated that tested parameters were as good as the control (0\%).
\end{abstract}

Key words: Cinnamomum burmannii leaves, meat quality, vaname shrimp 


\section{PENDAHULUAN}

Udang vaname merupakan salah satu komoditas akuakultur bernilai ekonomis tinggi dan dapat menunjang kebutuhan manusia akan gizi, terutama sumber protein hewani. Masyarakat menyukai daging udang karena mempunyai rasa yang enak dan kandungan zat gizi yang tinggi. Secara global permintaan udang vaname mengalami peningkatan sebesar 17\% tahun 2019 dibandingkan pada tahun 2018 (FAO GLOBEFISH, 2020). Kualitas produk udang vaname dapat ditunjang dengan manajemen budidaya baik serta dipengaruhi oleh pakan dan kondisi lingkungan budidaya, terutama salinitas (Sriket et al., 2007). Karakteristik atau kualitas daging dan rasa pada produk akuakultur akan dipengaruhi oleh peningkatan atauypun penurunan dari pakan yang dikonsumsi dan terseduanya pakan yang berkualitas. Adapun salah satu faktor yang mempengaruhi komposisi kimia daging ikan yaitu pakan yang dikonsumsi (Thammapat et al., 2010).

Kayu manis merupakan spesies dari genus Cinnamomum dengan famili Lauraceae yang memiliki senyawa polifenol, sinamaldehid, tanin dan flavonoid sebagai tanaman herbal (Jayaprakasha dan Rao 2011; Vangalapati et al., 2012; Azima et al. 2004; Prasad et al., 2009). Sinamaldehid merupakan senyawa terbesar penyusun daun kayu manis (Khazanah et al., 2017) dan dapat membentuk biomasa daging dengan cara peningkatan deposisi protein dalam pembentukan otot dari adanya peningkatan biosintesis protein dan kolagen (Takasao et al., 2012). Senyawa polifenol dan antioksidan mampu menghambat terbentuknya trigliserida yang merupakan deposit utama lemak dalam tubuh (Ciftci et al., 2010).

Informasi penelitian kayu manis telah banyak dilakukan pada ikan diantaranya Jusadi et al. (2016) melaporkan bahwa kualitas daging menjadi kompak dan memiliki rasa lebih manis dengan pemberian tepung daun kayu manis sebesar $1 \%$ pada ikan mas. Pemberian tepung daun kayu manis sebesar $1 \%$ juga dapat menurunkan lemak daging sebesar $37-50 \%$ dan kadar lemak tubuh sebesar $10-12 \%$. Penggunaan daun kayu manis sebesar $0,5 \%$ pada pakan ikan patin menghasilkan tekstur daging terbaik dan protein daging tertinggi (Setiawati et al., 2015). Hasil penelitian Palupi et al. (2020) menunjukkan bahwa pemberian tepung daun kayu manis mampu meningkatkan kualitas tekstur daging ikan nila dengan perlakuan terbaik pada 30 hari dibandingkan 60 hari.

Berdasarkan informasi yang telah dipaparkan sebelumnya, daun kayu manis berpotensi untuk dikembangkan dan dimanfaatkan sebagai suplemen pakan untuk meningkatkan kualitas daging udang vaname. Namun informasi terkait penggunaan tepung daun kayu manis pada pakan udang vaname belum banyak diketahui. Penelitian ini bertujuan untuk mengaplikasikan pemberian tepung daun kayu manis pada pakan terhadap kualitas daging udang vaname. 


\section{METODE PENELITIAN}

Penelitian ini menggunakan udang vaname Litopenaeus vannamei bobot rata-rata 10,06 $\pm 0,15 \mathrm{~g} \mathrm{ekor}^{-1}$ yang dipelihara pada akuarium berukuran $60 \mathrm{~cm} x$ $40 \mathrm{~cm}$ x $40 \mathrm{~cm}$ sebanyak 15 ekor setiap akuarium selama 60 hari. Penelitian dilaksanakan di Laboratorium Perikanan, Sekolah Vokasi IPB, analisa proksimat dilakukan di Laboratorim Nutrisi Departemen Budidaya Perairan (BDP), Fakultas Perikanan dan IImu Kelautan (FPIK), Institut Pertanian Bogor (IPB) sedangkan uji organoleptik dilakukan di Laboratorium Olah, Sekolah Vokasi IPB. Udang uji diberikan pakan pelet komersial (protein 34\%) kemudian penambahan daun kayu manis sesuai perlakuan yang dibuat dengan metode coating pada pakan perlakuan. Pemberian pakan pada udang diberikan sebanyak 3 kali sehari yaitu pada pukul 08.00 WIB, 12.00 WIB, 16.00 WIB dengan metode at satiation.

Penelitian yang dilakukan terdiri atas 4 perlakuan dengan 3 ulangan yaitu pakan komersial tanpa penambahan tepung daun kayu manis $(0 \%)$, pakan komersial yang ditambahkan tepung daun kayu manis $0,5 \%$, pakan komersial yang ditambahkan tepung daun kayu manis 1,0\% dan pakan komersial yang ditambahkan tepung daun kayu manis $1,5 \%$. Komposisi nilai nutrisi pakan disajikan pada Tabel 1. Parameter yang diamati terdiri dari proksimat daging udang vaname (kadar air, abu, protein, lemak dan serat kasar), glukosa, HDL dan analisis organoleptik daging udang vaname (aroma, warna, tekstur dan rasa).

Tabel 1 Komposisi nilai nutrisi pakan udang dengan perlakuan penambahan tepung daun kayu manis pada udang vaname

\begin{tabular}{cccccc}
\hline $\begin{array}{c}\text { Perlakuan } \\
(\%)\end{array}$ & $\begin{array}{c}\text { Kadar Air } \\
(\%)\end{array}$ & $\begin{array}{c}\text { Kadar Abu } \\
(\%)\end{array}$ & $\begin{array}{c}\text { Protein } \\
(\%)\end{array}$ & $\begin{array}{c}\text { Lemak } \\
(\%)\end{array}$ & $\begin{array}{c}\text { Serat } \\
\text { Kasar } \\
(\%)\end{array}$ \\
\hline 0 & 6,99 & 12,08 & 34,20 & 7,59 & 2,41 \\
0,5 & 8,69 & 13,01 & 34,13 & 7,71 & 1,15 \\
1,0 & 9,11 & 11,68 & 34,16 & 7,95 & 1,26 \\
1,5 & 8,46 & 11,85 & 34,90 & 8,20 & 1,22 \\
\hline
\end{tabular}

\section{Analisis Proksimat}

Analisis proksimat daging udang menggunakan metode AOAC (2012) yang terdiri dari air, abu, protein, lemak, dan serat kasar. Analisis kadar air dengan pemanasan dalam oven $\left(105-110^{\circ} \mathrm{C}\right)$, kadar protein dengan metode Kjeldahl, lemak dengan metode Soxhlet, kadar abu dengan pemanasan dalam tanur (400$600^{\circ} \mathrm{C}$ ) dan kadar serat kasar diukur dengan pelarutan dalam asam dan basa kuat serta pemanasan.

\section{Analisis Glukosa dan HDL}

Pengukuran kadar glukosa dan HDL pada hemolim udang dilakukan pada akhir pemeliharaan. Analisis glukosa dilakukan menggunakan metode berdasarkan Wedemeyer dan Yasutake (1977), sedangkan analisis HDL 
menggunakan kit Human Cholesterol liquicolor Precipitant and Standard (Human $\mathrm{mbH}$ Jerman).

\section{Analisis Organoleptik Daging Udang}

Analisis organoleptik daging udang dilakukan dengan menggunakan uji perbandingan jamak (multiple comparison test) dengan parameter aroma, warna, tekstur dan rasa. Uji ini dilakukan untuk mengetahui apakah ada perbedaan antara 3 perlakuan sampel (penambahan tepung daun kayu manis dengan konsentrasi $0,5 \%, 1,0 \%$ dan $1,5 \%)$ dengan sampel kontrol $(0 \%)$ atau pembanding $(\mathrm{P})$. Ketiga sampel dievaluasi seberapa berbeda masing-masing sampel dengan $\mathrm{P}$.

Daging udang yang akan diujikan direbus terlebih dahulu selama 5 menit dari mendidih, kemudian disajikan kepada 15 orang panelis. Panelis disajikan sampel $P$, kemudian 3 sampel dinilai dengan menggunakan skala yang menunjukkan tingkat perbedaan dengan $P$. Masing-masing sampel dibandingkan dengan $P$. Skala yang digunakan meliputi: sangat lebih baik dari $P(7)$, lebih baik dari $P(6)$, agak lebih baik dari $P(5)$, sama baiknya dengan $P(4)$, agak lebih buruk dari $P(3)$, lebih buruk dari $P(2)$ dan sangat lebih buruk dari $P(1)$.

\section{Analisis Data}

Penelitian dilakukan menggunakan Rancangan Acak Lengkap (RAL) dengan 4 perlakuan dengan 3 ulangan. Data hasil uji proksimat daging, glukosa, HDL dan organoleptik dianalisis secara deskriptif dan atau dengan ANOVA menggunakan SPSS 25. Uji lanjut Duncan dilakukan untuk data yang berbeda nyata $(p<0,05)$.

\section{HASIL DAN PEMBAHASAN}

\section{Komposisi Kimia Daging Udang}

Komposisi kimia daging udang meliputi pengukuran proksimat daging, glukosa dan HDL yang diakukan setelah pemeliharaan 60 hari. Hasil analisis proksimat daging udang, glukosa dan HDL dan disajikan pada Tabel 2.

Tabel 2 Hasil analisis proksimat daging, glukosa dan HDL udang vaname

\begin{tabular}{lcccc}
\hline \multirow{2}{*}{ Parameter uji } & \multicolumn{4}{c}{ Perlakuan penambahan tepung daun kayu manis (\%) } \\
\cline { 2 - 5 } & 0 & 0,5 & 1,0 & 1,5 \\
\hline Air (\%) & $76,01 \pm 1,40^{\mathrm{a}}$ & $76,94 \pm 0,79^{\mathrm{a}}$ & $75,54 \pm 0,76^{\mathrm{a}}$ & $75,67 \pm 1,56^{\mathrm{a}}$ \\
Abu (\%) & $2,68 \pm 0,49^{\mathrm{a}}$ & $2,80 \pm 0,14^{\mathrm{a}}$ & $2,43 \pm 0,17^{\mathrm{a}}$ & $2,68 \pm 0,47^{\mathrm{a}}$ \\
Protein (\%) & $16,52 \pm 0,84^{\mathrm{a}}$ & $16,79 \pm 0,29^{\mathrm{a}}$ & $17,09 \pm 1,08^{\mathrm{a}}$ & $17,10 \pm 0,89^{\mathrm{a}}$ \\
Lemak (\%) & $1,72 \pm 0,09^{\mathrm{a}}$ & $1,58 \pm 0,28^{\mathrm{a}}$ & $1,52 \pm 0,41^{\mathrm{a}}$ & $1,46 \pm 0,28^{\mathrm{a}}$ \\
Serat kasar (\%) & $1,56 \pm 0,16^{\mathrm{a}}$ & $1,56 \pm 0,22^{\mathrm{a}}$ & $1,71 \pm 0,14^{\mathrm{a}}$ & $1,59 \pm 0,38^{\mathrm{a}}$ \\
Glukosa (mg/100 & $64,80 \pm 2,12^{\mathrm{c}}$ & $52,33 \pm 2,52^{\mathrm{b}}$ & $37,20 \pm 2,88^{\mathrm{a}}$ & $38,53 \pm 3,29^{\mathrm{a}}$ \\
mL) & $92,72 \pm 1,75^{\mathrm{a}}$ & $95,34 \pm 0,92^{\mathrm{a}}$ & $96,55 \pm 2,16^{\mathrm{a}}$ & $96,75 \pm 4,19^{\mathrm{a}}$ \\
HDL (mg/dL) & 9 & &
\end{tabular}


Dari Tabel 2 menunjukkan hasil analisis proksimat daging udang vaname (kadar air, abu, protein, lemak dan serat kasar) dan HDL secara statistik tidak berbeda nyata untuk semua perlakuan $(p>0,05)$. Sedangkan kandungan glukosa udang vaname secara statistik berbeda nyata $(p<0,05)$.

Kadar lemak daging udang menunjukkan kecenderungan menurun dengan bertambahnya konsentrasi pemberian tepung daun kayu manis, walaupun secara statistik tidak berbeda nyata $(p>0,05)$. Hasil penelitian lain yaitu Setiawati et al. (2016) dan Palupi et al. (2020) menunjukkan semakin bertambahnya pemberian dosis daun kayu manis yang ditambahkan pada pakan terjadi penurunan lemak pada daging ikan nila. Penurunan kadar lemak diduga karena komponen bioaktif yang terdapat dalam daun kayu manis, di antaranya tanin (Cheng et al., 2012), sinamaldehid (Rohmah 2010), dan flavonoid (Prasad et al., 2009). Udang dapat melakukan metabolisme lain dari pemanfaatan lemak sebagai sumber energi. Lipid yang tersimpan ditransportasikan pada beberapa organ dan jaringan selama waktu tertentu seperti pada stadia premolt (Priya et al., 2013). Pertumbuhan akan maksimal dengan adanya lemak yang digunakan sebagai sumber energi (Boonyaratpalin, 1996). Kandungan HDL pada daging udang vaname secara statistik tidak berbeda nyata untuk semua perlakuan $(p>0,05)$. Hasil penelitian Setiawati (2016) menunjukkan perlakuan ekstrak daun kayu manis dengan konsentrasi $0 ; 0,5 ; 1,0 ; 2,0$; dan $4,0(\mathrm{~g} / \mathrm{kg})$ tidak menyebabkan perbedaan kandungan HDL pada daging ikan patin.

Kadar serat kasar daging udang secara statistik tidak berbeda nyata untuk semua perlakuan ( $p>0.05$ ). Serat kasar merupakan bagian dari karbohidrat. Udang memerlukan karbohidrat dalam jumlah besar, karena selain diperlukan sebagai pembakar dalam proses metabolisme, juga diperlukan dalam sintesis kitin dalam kulit keras. Kemampuan udang untuk memanfaatkan karbohidrat sebesar 20-30\% (Wang et al., 2016) sehingga pemanfaatan karbohidrat mampu lebih efektif sebagai sumber energi.

Kadar glukosa udang vaname pada semua perlakuan secara statistik berbeda nyata $(p<0,05)$. Semakin tinggi konsentrasi tepung daun kayu manis yang ditambahkan, kadar glukosa cenderung semakin menurun. Nilai glukosa dari semua perlakuan masih berada dalam kisaran normal (kurang dari $150 \mathrm{mg} / \mathrm{dL}$ ). Kayu manis mampu menstimulasi penyerapan glukosa (Jarvill et al., 2001). Glukosa diserap ke dalam aliran darah untuk dijadikan energi pertumbuhan dan aktivitas metabolisme, hal tersebut terjadi karena adanya peningkatan aktivitas insulin oleh sinamaldehid yang terkandung dalam daun kayu manis (Guo et al., 2017)

\section{Kualitas Daging Udang Secara Organoleptik}

Tujuan dari uji organoleptik dengan metode perbandingan jamak adalah untuk mengetahui apakah ada perbedaan diantara satu atau lebih contoh dengan kontrol dan untuk memperkirakan besarnya perbedaan yang ada (Setyaningsih et al., 2010). Pada penelitian ini, satu contoh dijadikan sebagai kontrol atau P (perlakuan dengan konsentrasi $0 \%$ ), sedangkan 3 contoh lainnya (perlakuan dengan konsentrasi $0,5 \%, 1,0 \%$ dan 1,5\%) dievaluasi apakah ada perbedaan 
antara masing-masing contoh dengan kontrol (P) (Gambar 1). Analisis organoleptik dilakukan untuk parameter aroma, tekstur, warna dan rasa daging udang.

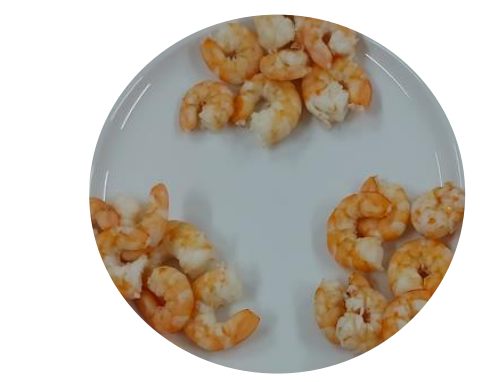

(a)

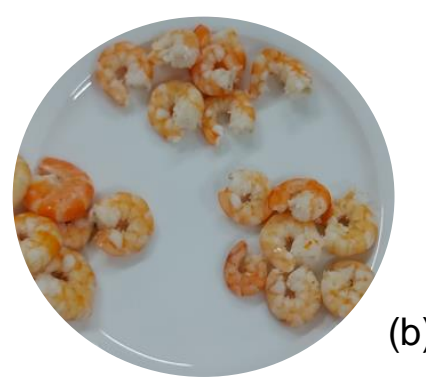

(c)
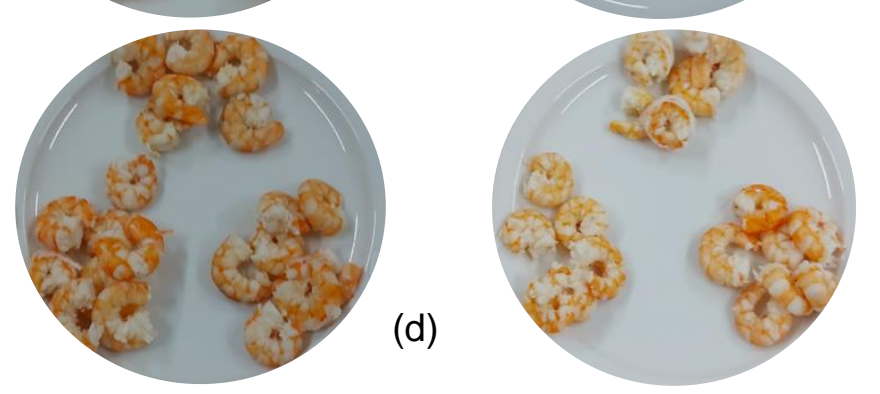

Gambar 1 Daging udang vaname dengan perlakuan penambahan tepung daun kayu manis: $0 \%$ atau $\mathrm{P}(\mathrm{a}), 0,5 \%$ (b), $1,0 \%$ (c) dan $1,5 \%$ (d)

Hasil uji organoleptik untuk parameter aroma menunjukkan rata-rata respon panelis terhadap aroma daging udang untuk perlakuan tepung daun kayu manis dengan konsentrasi $0,5 \%, 1,0 \%$ dan $1,5 \%$ berturut-turut 4,43, 4,31 dan 4,45. Nilainilai ini jika dibandingkan dengan $\mathrm{P}$, berada di atas 4 , dimana nilai 4 artinya aroma daging udang sama baiknya dengan contoh $P$ (Gambar 2). Hal ini menunjukkan aroma daging udang berada pada range sama baiknya dan agak lebih baik dibandingkan dengan $\mathrm{P}$.

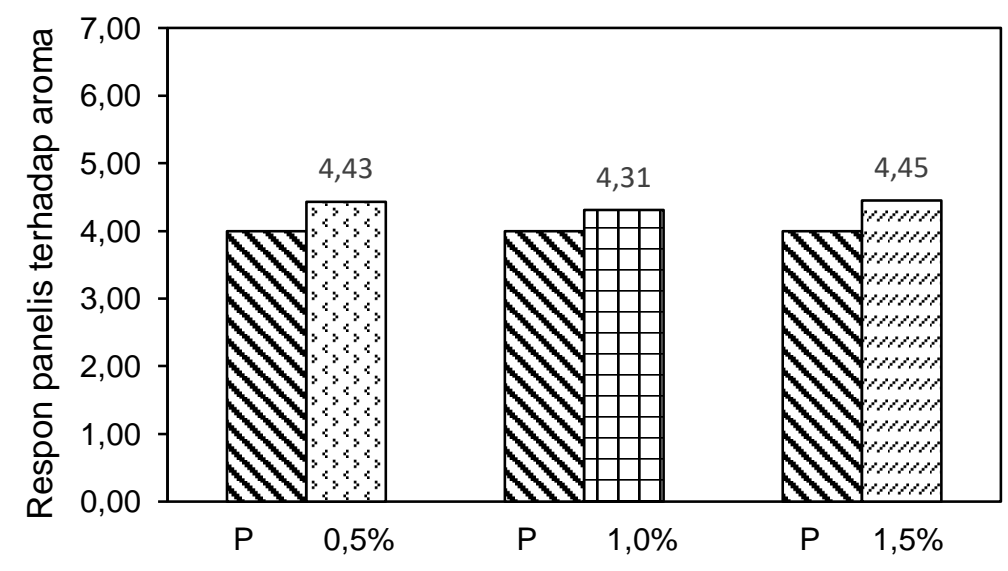

Penambahan tepung daun kayu manis

Gambar 2 Rata-rata respon panelis terhadap aroma daging udang 
Hasil ANOVA terhadap parameter aroma daging udang menunjukkan bahwa tidak ada perbedaan yang nyata dari ketiga contoh yang diuji dibandingkan dengan kontrol atau $P(p>0,05)$. Hal ini menunjukkan penambahan tepung daun kayu manis dengan konsentrasi $0,5 \%, 1,0 \%$ dan $1,5 \%$ tidak menghasilkan perbedaan aroma yang dapat dideteksi oleh panelis.

Hasil uji organoleptik untuk parameter warna menunjukkan rata-rata respon panelis terhadap warna daging udang untuk perlakuan tepung daun kayu manis dengan konsentrasi $0,5 \%, 1,0 \%$ dan 1,5\% berturut-turut 4,67, 4,67 dan 4,60 Nilanilai ini jika dibandingkan dengan $\mathrm{P}$, berada di atas 4 , dimana nilai 4 artinya warna daging udang sama baiknya dengan contoh P (Gambar 3). Hal ini menunjukkan warna daging udang berada pada range sama baiknya dan agak lebih baik dibandingkan dengan $\mathrm{P}$.

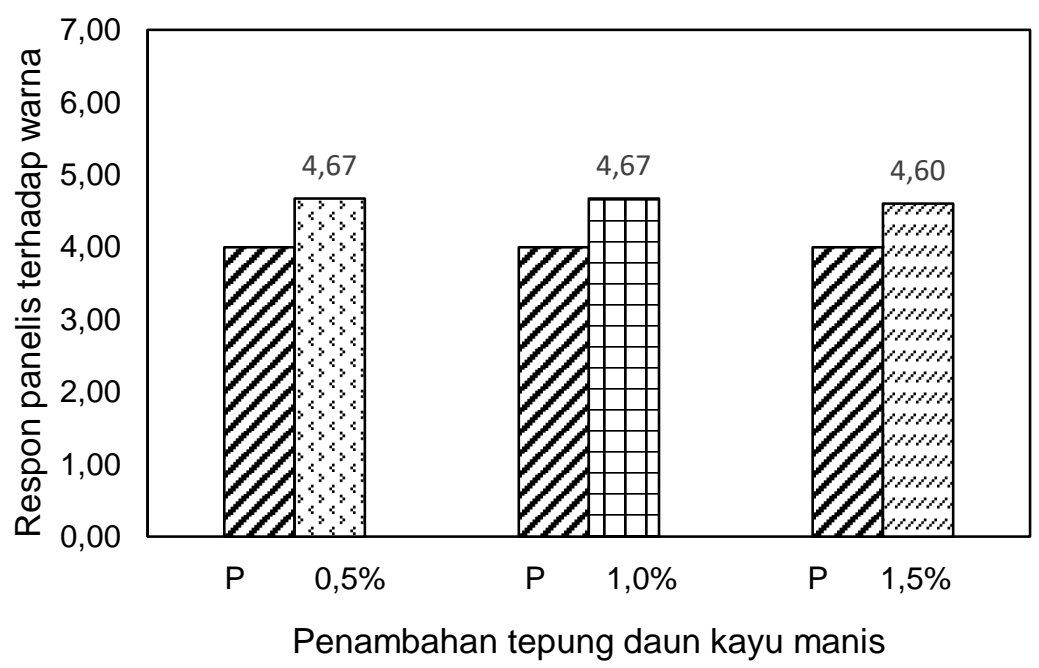

Gambar 3 Rata-rata respon panelis terhadap warna daging udang

Hasil ANOVA terhadap parameter warna daging udang menunjukkan bahwa tidak ada perbedaan yang nyata dari ketiga contoh yang diuji dibandingkan dengan kontrol atau $P(p>0,05)$. Hal ini menunjukkan penambahan tepung daun kayu manis dengan konsentrasi $0,5 \%, 1,0 \%$ dan $1,5 \%$ tidak menghasilkan perbedaan warna yang dapat dideteksi oleh panelis.

Hasil uji organoleptik untuk parameter tesktur menunjukkan rata-rata respon panelis terhadap tekstur daging udang untuk perlakuan tepung daun kayu manis dengan konsentrasi $0,5 \%, 1,0 \%$ dan $1,5 \%$ berturut-turut 4,52, 4,67 dan 4,52 Nilanilai ini jika dibandingkan dengan $\mathrm{P}$, berada di atas 4 , dimana nilai 4 artinya warna daging udang sama baiknya dengan contoh P (Gambar 4). Hal ini menunjukkan warna daging udang berada pada range sama baiknya dan agak lebih baik dibandingkan dengan $P$. 


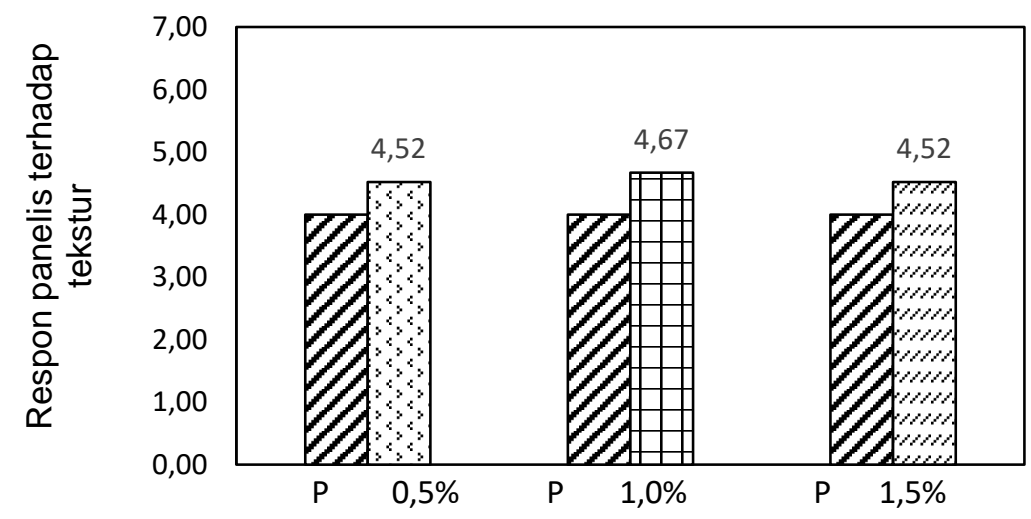

Penambahan tepung daun kayu manis

Gambar 4 Rata-rata respon panelis terhadap tekstur daging udang

Hasil ANOVA terhadap parameter tekstur daging udang menunjukkan bahwa tidak ada perbedaan yang nyata dari ketiga contoh yang diuji dibandingkan dengan kontrol atau $\mathrm{P}(\mathrm{p}>0,05)$. Hal ini menunjukkan penambahan tepung daun kayu manis dengan konsentrasi $0,5 \%, 1,0 \%$ dan 1,5\% tidak menghasilkan perbedaan tekstur yang dapat dideteksi oleh panelis.

Hasil uji organoleptik untuk parameter rasa menunjukkan rata-rata respon panelis terhadap rasa daging udang untuk perlakuan tepung daun kayu manis dengan konsentrasi $0,5 \%, 1,0 \%$ dan $1,5 \%$ berturut-turut $4,48,4,38$ dan 4,52 Nilanilai ini jika dibandingkan dengan $\mathrm{P}$, berada di atas 4 , dimana nilai 4 artinya warna daging udang sama baiknya dengan contoh $P$ (Gambar 5). Hal ini menunjukkan rasa daging udang berada pada range sama baiknya dan agak lebih baik dibandingkan dengan $\mathrm{P}$.

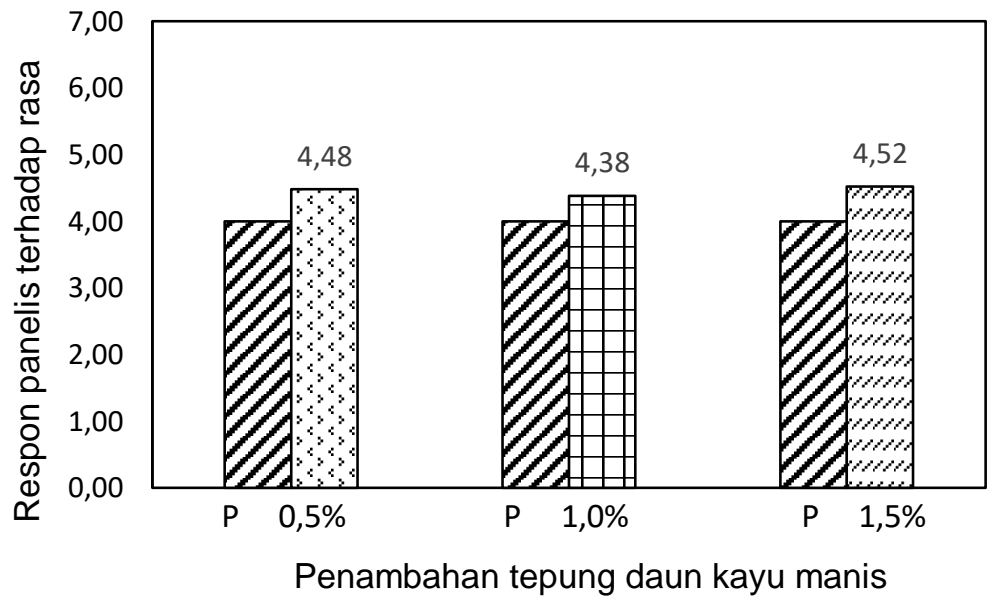

Gambar 5 Rata-rata respon panelis terhadap rasa daging udang

Hasil ANOVA terhadap parameter rasa daging udang menunjukkan bahwa tidak ada perbedaan yang nyata dari ketiga contoh yang diuji dibandingkan dengan 
kontrol atau $P(p>0,05)$. Hal ini menunjukkan penambahan tepung daun kayu manis dengan konsentrasi $0,5 \%, 1,0 \%$ dan $1,5 \%$ tidak menghasilkan perbedaan rasa yang dapat dideteksi oleh panelis.

Hasil penelitian Palupi et al. (2020) mengenai penambahan tepung daun kayu manis sebanyak $1 \%$ pada daging ikan nila (Orechromis niloticus), untuk uji kualitas warna daging ikan (rednes, yellowness dan lightness) menggunakan chromameter, secara statistik tidak berbeda nyata untuk semua perlakuan $(p>0,05)$. Perlakuan yang digunakan adalah pemberian pakan selama 15 hari (15D), 30D, 45D dan 60D. Untuk hasil analisis tekstur menggunakan texture analyzer menunjukkan bahwa perlakuan 15D tidak berbeda nyata dengan kontrol dan 45D.

Dari hasil pengujian organoleptik tersebut, penambahan tepung daun kayu manis dengan konsentrasi $0,5 \%, 1,0 \%$ dan $1,5 \%$ tidak menghasilkan perbedaan aroma, warna, rasa dan tekstur daging udang yang dapat dideteksi oleh panelis ( $p>0,05)$. Hal ini menunjukkan mungkin diperlukan penelitian lanjutan dengan penambahan konsentrasi tepung daun kayu manis yang lebih tinggi dari $1,5 \%$ yang mungkin akan menghasilkan perbedaan aroma, warna, rasa dan tekstur yang dapat dideteksi oleh panelis.

Hasil pengujian organoleptik dapat dipengaruhi oleh beberapa faktor diantaranya beragamnya keterandalan panelis dalam melakukan pengujian. Panelis kemungkinan tidak semuanya memiliki pemahaman yang sama terhadap skala perbedaan yang digunakan untuk menilai perbedaan sampel. Sebelum dilakukan pengujian, panelis diinformasikan mengenai teknis cara pengujian untuk menilai perbedaan sampel dengan pembanding, hanya saja panelis kemungkinan tidak semuanya memiliki pemahaman yang sama terhadap skala perbedaan yang untuk menilai perbedaan sampel. Penilaian organoleptik bersifat subjektif, sehingga ke depan diperlukan pengujian lainnya seperti pengujian secara fisik yang bersifat objektif, misalnya untuk parameter warna diuji menggunakan chromameter dan parameter tekstur dengan texture analyzer.

\section{SIMPULAN}

Hasil analisis proksimat daging udang vaname (kadar air, abu, protein, lemak dan serat kasar) dan HDL secara statistik tidak berbeda nyata untuk semua perlakuan $(p>0,05)$, sedangkan kadar glukosa secara statistik berbeda nyata $(p<0,05)$. Hasil pengujian organoleptik terhadap kualitas daging udang menunjukkan penambahan tepung daun kayu manis dengan konsentrasi $0,5 \%$, $1,0 \%$ dan $1,5 \%$ tidak menghasilkan perbedaan aroma, warna, rasa dan tekstur daging udang yang dapat dideteksi oleh panelis $(p>0,05)$, akan tetapi semua parameter, rata-rata respon panelis menunjukkan angka di atas 4 , melebihi nilai kontrol.

\section{SARAN}


Diperlukan penelitian lanjutan dengan penambahan konsentrasi tepung daun kayu manis yang lebih tinggi dari 1,5\% yang mungkin akan menghasilkan perbedaan aroma, warna, rasa dan tekstur yang dapat dideteksi oleh panelis. Diperlukan pengujian lainnya secara fisik yang bersifat objektif, diantaranya untuk parameter warna dengan chromameter dan parameter tekstur dengan texture analyzer untuk mendukung data pengujian secara organoleptik.

\section{DAFTAR PUSTAKA}

[AOAC] Association of Official Analytical Chemists. 2012. Official Methods of Analysis, 19th ed. Airlington: AOAC.

Azima F, Muchtadi D, Zakaria FR, Priosoeryanto. 2004. Potensi antihiperkolesterolemia ekstrak cassia vera Cinnamomum burmanni nees et Blumo. Jurnal Teknologi Dan Industri Pangan. 15:145-153.

Boonyaratpalin M. 1996. Nutritional Requirements of Commercially Important Shrimp in the Tropics. Proceedings of the National Seminar Workshop on Fish Nutrition and Feeds. SEAFDEC Aquaculture Department, Iloilo, Philippines.

Cheng D, Peter K, Alexander P, Leonel ER, Mary AL, llya R. 2012. In vivo and in vitro antidiabetic effect of aqueous cinnamon extract and cinnamon polyphenol-enhanced food matrix. Food Chemistry. 135: 2 994-3 002.

Ciftci M, Simsek UG, Yuce A, Yilmaz O, Dalkilic. 2010. Effect of dietary antibiotic and cinnamon oil suplementation on antioxidant enzyme activities, cholesterol level and fatty acid compotitions of serum and met in broiler chickens. Acta Veterinary. 79:33-40.

FAO GLOBEFISH. 2020. COVID-19 dampens the initially positive shrimp forecast forecast for 2020 (Posting on July 8 th 2020). http://www.fao.org/inaction/globefish/market-reports. [diunduh pada 21 Maret 2021].

Guo X, Sun W, Huang L, Wu L, Hou Y, Qin L, Liu T. 2017. Effect of cinnamaldehyde on glucose metabolisme and vessel function. Medical Science Monitor. (23): 3844-3853.

Jarvill TKJ, Anderson RA, Graves DJ. 2001. A hydroxychalcone derived from cinnamon functions as a mimetic for insulin in 3T3-L1 adipocytes. J. Am. Coll. Nutr. 20:327-336. https://doi.org/10.1080/07315724.2001.10719053.

Jayaprakasha GK, Rao LJM. 2011. Chemistry, biogenesis, and biological activities of Cinnamomum zeylanicum. Crit. Rev. Food Sci. Nutr. 51, 547-562. https://doi.org/10.1080/10408391003699550.

Jusadi D, Hutama AA, Nurhayati T, Wasjan, Vinasyiam A. 2016. Growth performance and flesh quality of common carp, (Cyprinus carpio) feeding on the diet supplemented with cinnamon (Cinnamomum burmannii) leaf. $A A C L$ Bioflux. 9(5): 937-943.

Khazanah LU, Anadhito BK, Uyun Q, Utami R, Manuhara GJ. 2017. Optimasi proses ekstraksi dan karakterisasi oleoresin daun kayu manis (Cinnamomum burmannii). Indonesian Journal of Essential Oil. 2(1): 20-28. 
Palupi TR, Setiawati M, Jusadi D, Fauzi IA, Wasjan. 2020. Evaluasi periode pemberian pakan mengandung daun kayu manis Cinnamomum burmannii terhadap kualitas daging ikan nila Oreochromis niloticus. Jurnal Pengolahan Hasil Perikanan Indonesi. 23(1):178-185.

Prasad KN, Yang B, Dong X, Jiang G, Zhang H, Xie H, Jiang Y. 2009. Flavonoid contents and antioxidant activities from Cinnamomum spesies. Innovative Food Science and Emerging Technologies. 10(4): 627-632.

Priya ERKLJ, Kala S, Ravichandran, and Chandran M. 2013. Variation of lipid concentration in some edible crabs. Journal of Fish and Marine Sciences. $5(1): 110-112$.

Rohmah M. 2010. Aktifitas antioksidan campuran kopi robusta Coffea cannephora dengan kayu manis Cinnamomum burmanii. Jurnal Teknologi Pertanian. 6: 50-54.

Setiawati M, Jusadi D, Rolin F, Vinasyiam A. 2016 Evaluasi pemberian ekstra daun kayu manis Cinnamomun burmannii pada pakan terhadap kandungan lemak daging ikan patin Pangasianodon hypopthalmus. Jurnal Akuakultur Indonesia. 15(2): 132-138.

Setiawati M, Sakinah A, Jusadi D. 2015. Evaluasi pertumbuhan dan kualitas daging ikan patin Pangasianodon hypopthalmus yang diberi pakan mengandung daun kayu manis Cinnamomun burmannii. Jurnal Akuakultur Indonesia. 14(2): 171-178.

Setyaningsih D, Apriyantono A, Sari MP. 2010. Analisis Sensori untuk Industri Pangan dan Agro. IPB Press. Bogor. 43-49.

Sriket P, Benjakul S, Visessanguan W, Kijroongrojana K. 2007. Comparative studies on chemical composition and thermal properties of black tiger shrimp (Penaeus monodon) and white shrimp (Penaeus vannamei) meats. Food Chemistry. 103: 1119-1207.

Thammapat P, Raviyan P, Siriamornpun S. 2010. Proximate and fatty acid composition of the muscles and viscera of Asian catfish Pangasius bocourty. Food Chemistry. 122: 223-227.

Takasao N, Tsuji-Naito K, Ishikura S, Tamura A, dan Akagawa M. 2012. Cinnamon extract promotes type i collagen biosynthesis via activation of igf-1 signaling in human dermal fibroblasts. Journal of Agricultural and Food Chemistry. 60:1193-1200.

Vangalapati M, Satya NS, Prakash DVS, Avaningadda S. 2012. A review on pharmacological activities and clinical effects of cinnamon spesies. Research Journal of Pharmaceutical Biological and Chemical Sciences. 3(1): 653-663.

Wang X, Li E, Chen L. 2016. A Review of carbohydrate nutrition and metabolism in Crustaceans. N. Am. J. Aquac. 78:178-187. https://doi.org/10.1080/15222055.2016.1141129.

Wedemeyer GA, Yasutake WT. 1977. Clinical methods for the assessment of the effects of environmental stress on fish health. Washington DC. 